
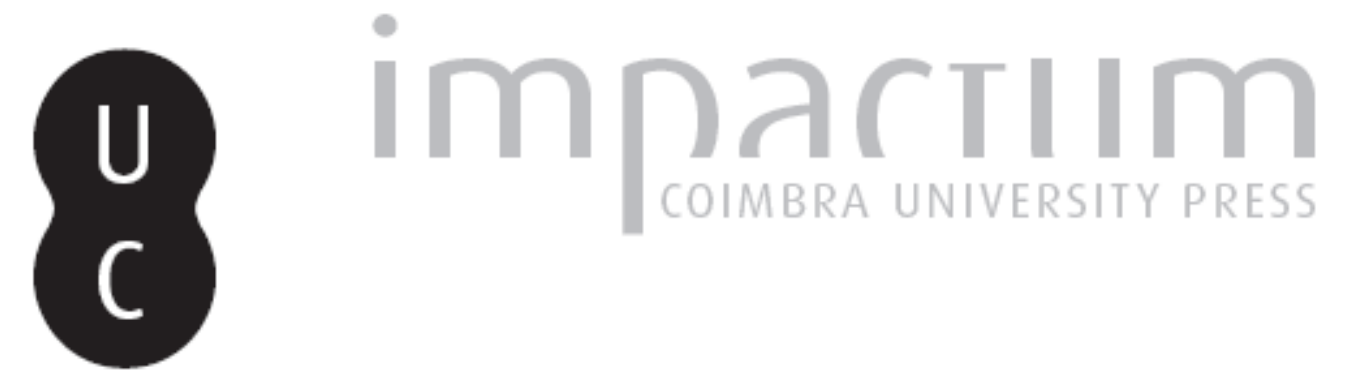

\title{
Sistema viário e dinâmicas produtivas pioneiras na porção leste da Amazônia setentrional brasileira
}

Autor(es): $\quad$ Silva, Olavo Fagundes da; Cunha, Lúcio

Publicado por: Imprensa da Universidade de Coimbra

URL persistente:

URI:http://hdl.handle.net/10316.2/40770

DOI:

DOI:https://doi.org/10.14195/0871-1623_35_1

Accessed : $\quad$ 26-Apr-2023 16:18:34

A navegação consulta e descarregamento dos títulos inseridos nas Bibliotecas Digitais UC Digitalis, UC Pombalina e UC Impactum, pressupõem a aceitação plena e sem reservas dos Termos e Condições de Uso destas Bibliotecas Digitais, disponíveis em https://digitalis.uc.pt/pt-pt/termos.

Conforme exposto nos referidos Termos e Condições de Uso, o descarregamento de títulos de acesso restrito requer uma licença válida de autorização devendo o utilizador aceder ao(s) documento(s) a partir de um endereço de IP da instituição detentora da supramencionada licença.

Ao utilizador é apenas permitido o descarregamento para uso pessoal, pelo que o emprego do(s) título(s) descarregado(s) para outro fim, designadamente comercial, carece de autorização do respetivo autor ou editor da obra.

Na medida em que todas as obras da UC Digitalis se encontram protegidas pelo Código do Direito de Autor e Direitos Conexos e demais legislação aplicável, toda a cópia, parcial ou total, deste documento, nos casos em que é legalmente admitida, deverá conter ou fazer-se acompanhar por este aviso.

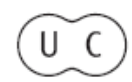




\section{Cadernos de}
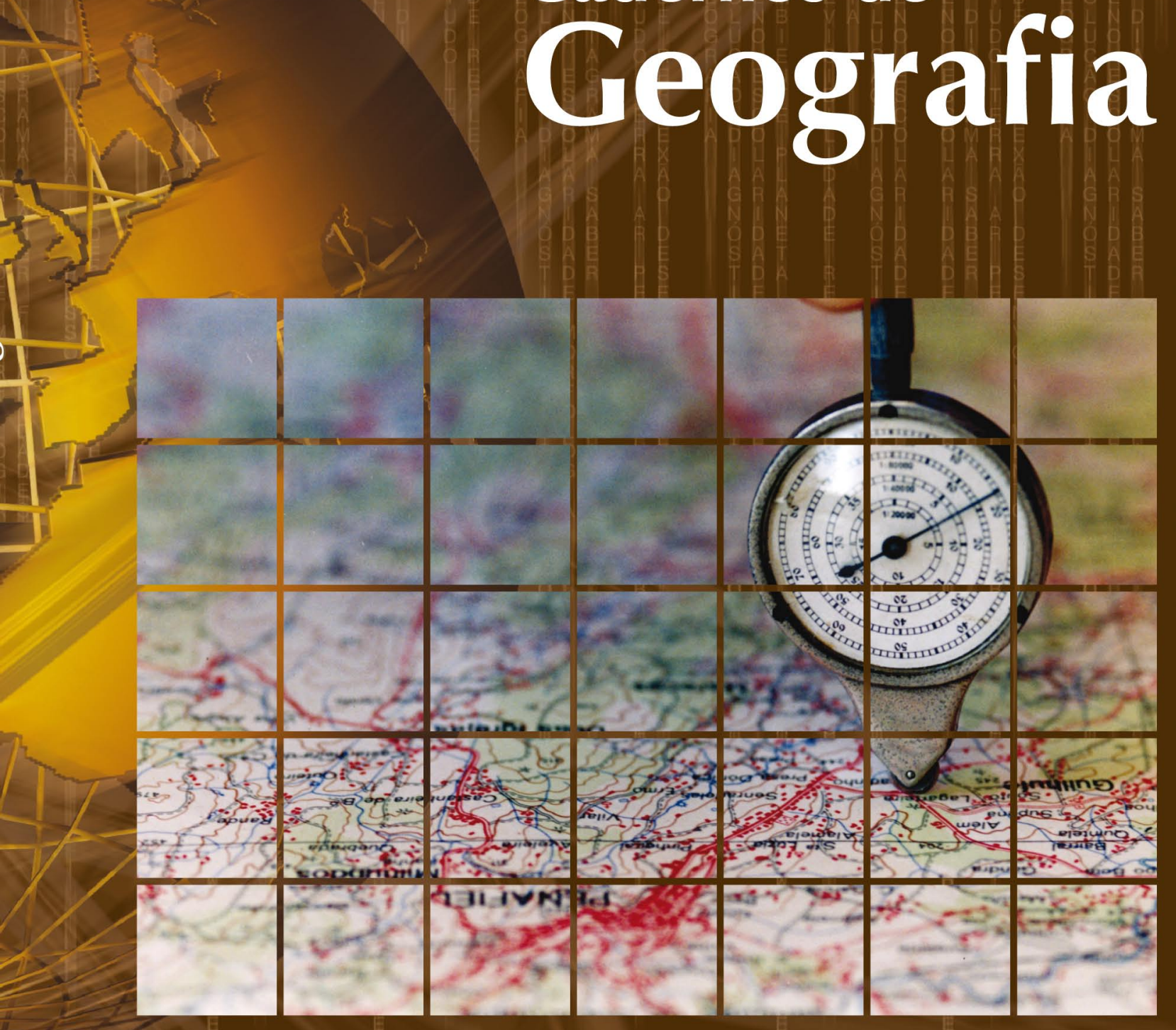

Imprensa da Universidade de Coimbra

Faculdade de Letras | Universidade de Coimbra 


\section{Sistema viário e dinâmicas produtivas pioneiras na porção leste da Amazônia setentrional brasileira Transport system and pioneering production dynamics in the eastern portion
of the northern brazilian Amazon}

\section{Olavo Fagundes da Silva}

Universidade de Coimbra, Faculdade de Letras, Programa de Doutoramento em Geografia, Bolsista do CNPq- Brasil. fagundesolavo@gmail.com

\section{Lúcio Cunha}

Universidade de Coimbra, Faculdade de Letras, Departamento de Geografia / CEGOT.

luciogeo@ci.uc.pt

\section{Resumo:}

Na Amazônia setentrional brasileira as grandes distâncias a serem percorridas e a barreira natural imposta pelo Rio Amazonas, constituiram uma grande dificuldade para a atuação do Estado Nacional brasileiro até ao fim da primeira metade do século XX. Na sua porção leste, apesar da incipiência do Estado, as dinâmicas de desenvolvimento regional baseadas no extrativismo florestal permitiram manter relativa soberania sobre o território que também era reclamado pelos franceses. Logo após a descoberta das jazidas de manganês em Serra do Navio, no início da década de 1940, o Brasil consolidou sua soberania através da criação do Território Federal do Amapá e da dotação de uma estrutura administrativa que pegou embalo na infraestrutura para exploração mineral implantada pela inciativa privada do capital nacional associado ao internacional. Observando esse período histórico, tentou-se, com base na avaliação das estruturas fixadas no espaço, efetuar um estudo que pudesse indicar como o sistema viário evoluiu nesta região do país e qual sua relação com as dinâmicas pioneiras de desenvolvimento regional. Constatou-se que o sistema viário no Amapá apresentava uma relação direta com as dinâmicas extrativistas e que a sua evolução em grande medida se deveu à expansão ou retração gradativa do processo produtivo nessas atividades.

Palavras-Chave: Amapá. Dinâmicas pioneiras. Extrativismo. Sistema viário.

\section{Abstract:}

In the northern Brazilian Amazon the large distances to be covered and natural barrier by the Amazon River, imposed great difficulty to the performance of the Brazilian National State until the end of the first half of the twentieth century. In the eastern portion, despite the insipience of state, dynamics of regional development based on forest extraction helped maintain relative sovereignty over the territory which was also contested by the French. After the discovery of manganese deposits in Serra do Navio in the early 1940s, Brazil consolidated its sovereignty through the creation of the Federal Territory of Amapá and the provision of an administrative structure that took momentum in infrastructure for mineral exploration implemented by initiative private national capital associate to international. Noting that historical period, an attempt was made based on the evaluation of the structures established in the space make a study that could indicate how the road system evolved in this region of the country and what their relationship to dynamic pioneer of regional development. It was found that the transport system in Amapá had a directly proportional relation to the extractive dynamics and their evolution largely due to the expansion or gradual decrease of the production process in these activities.

Keywords: Amapá. Pioneering dynamics. Extraction. Transport system.

\section{Introdução}

0 arcabouço teórico que sustenta o estudo dos transportes começou a ser sistematizado no alvorecer da perspectiva de uso e interação dos modais aquaviário, ferroviário e rodoviário, no final do século XIX e início do século XX. Em The Theory of
Transportation, Charles H. Cooley (1894: 13) definiu os transportes como "o movimento de coisas-massas de toda a sorte, de um lugar para outro". Cooley afirmava também que as características dos transportes na sua totalidade ou em cada unidade modal, num dado intervalo de tempo, eram determinadas pelas inter-relações das forças físicas e das condições sociais presentes. 0 autor estabeleceu ainda, que 
uma metodologia para a compreensão das dinâmicas nos transportes, deveria necessariamente levar em conta a análise dessas inter-relações (ob. cit.: 40).

Mas foi a partir de obras como a Géographie des Transports de Wolkowitch (1973) na França que o universo dos transportes passou a ganhar contornos de abordagem sistêmica. Para este autor, a abordagem dos transportes, enquanto sistema, deveria tomar como base a teoria dos lugares centrais. Essa teoria valorizava a análise dos fluxos considerando a capacidade de polarização das cidades centrais, onde estava a estrutura produtiva e para onde fluía a rede de transportes, e a periferia, onde estariam os lugares polarizados.

Estudos mais recentes sobre os sistemas de transportes como as obras de Pádula (2008) e Rodrigue et al. (2013) concentram seus esforços na tentativa de estudar o complexo de relações econômico-sociais e físico-territoriais que os caracterizam. Para Pádula (2008: 15) o sistema de transportes, bem como os sistemas energético e informacional são sustentáculos da economia contemporânea e os investimentos em infraestruturas de transportes não geram apenas produtos, mas são responsáveis pela produtividade de um país. De igual maneira, Rodrigue et al. ( 2013: 38) concordam que o sistema de transportes é resultado de uma composição das demandas econômico-sociais dos lugares servidos e das redes físicas que suportam os movimentos visando o desenvolvimento socioeconômico.

Na Amazónia e mais especificamente no Estado do Amapá, a adoção de estratégias de integração baseadas nos grandes eixos viários é, como no restante território brasileiro, resultante das metas e também das quimeras de integração e desenvolvimento do "Brasil grande", mitologicamente construído a partir das décadas de 50 e 60 do século XX. Essas estratégias de integração pensadas para levar "civilização" aos povos amazónicos, desprezando toda a vocação natural dos rios da região, tiveram seu grande impulso no Plano de metas do governo Juscelino Kubitschek e nos arroubos da implantação da indústria automobilística transnacional. A partir desse evento o planejamento estratégico brasileiro passaria a priorizar a abertura de grandes rodovias que pudessem fazer a integração do país e dar finalidade e fluxo aos novos arranjos espaciais que a indústria automobilística supostamente traria (Costa, 1997).

Posteriormente, nos planos dos governos militares, como forma de justificar e fomentar os investimentos das indústrias de montagem de automóveis passaram-se a adotar, como metas prioritárias do planejamento estratégico nacional, a construção de novas estradas e ampliação e melhoria das existentes. Dessa maneira, o Estado brasileiro acenava ao capital instalado das indústrias de montagem, a intenção de consolidar uma malha viária que pudesse dar utilidade e fluidez para o deslocamento de pessoas e escoamento da produção nacional, baseados no transporte automóvel.

Cabe lembrar que o desejo de fazer do Brasil um país com grandes eixos viários nacionais de desenvolvimento, já estava presente em projetos que remontam à segunda metade do século XIX. Acselrad (2001) relembra que essa postura do Estado nacional brasileiro já era evidenciada desde 1838 com o plano Rebelo, que priorizava a construção e expansão das ferrovias. Posteriormente, no ano de 1868, o plano Moraes pretendia integrar os eixos ferroviários existentes com a navegação de cabotagem. O objetivo destes planos pioneiros era fomentar o desenvolvimento do país com base no desenvolvimento dos transportes de larga escala.

A manutenção de linhas regulares de navegação de cabotagem e fluvial acabou se tornando um dos marcos da estratégia nacional para manter a soberania sobre os rincões mais distantes e isolados do país. No Amapá, território sobre o qual até ao início do século XX ainda pairavam as dúvidas de soberania entre Brasil e França, foi instalada uma rota entre Belém e Oiapoque, operada pela empresa de navegação The Amazon River Steam Navigation Company Limited que era subvencionada pelo Governo Central. 0 primeiro registro da operação entre as duas cidades data de 1934, mas a companhia já constava nas estatísticas de 1912 das empresas que operavam as rotas amazónicas (Maic, 1917: 26; INE, 1936: 163).

Até ao início do século XX, conforme afirma Acselrad (2001), a construção de estradas ainda não tinha suporte suficiente para deslanchar enquanto estratégia de estímulo ao desenvolvimento no país. Segundo o autor, foram as dificuldades impostas pelo sucateamento da maquinaria ferroviária e das próprias vias férreas, bem como o caos nas linhas de navegação e nos portos, que empurraram o país no sentido de procurar alternativas de tornar o transporte da produção mais eficiente para o capital, tanto no que tange à sua distribuição externa, quanto interna.

Desde meados do século XIX a lógica que imperava para delinear os contornos da distribuição espacial das terras no Brasil era definida pelo alcance da rede ferroviária. De acordo com Acserald (2001) os detentores da rede deveriam se apropriar das terras por onde esta se estendesse. Assim, os grandes proprietários de terra, estavam diretamente ligados ao processo de apropriação e uso dos espaços adjacentes à rede ferroviária. 0 autor coloca ainda em evidência, a constatação de que esse mecanismo de apropriação de terras baseado no binómio ferrovia/ terras vai ser reproduzido posteriormente, quando os detentores do uso prioritário das rodovias também se transformam nos grandes proprietários de terras.

O planejamento estratégico para a Amazónia brasileira tem sido alvo de estudos, tanto no Brasil com autores como Becker (1998) e Oliveira (1990), que se dedicam a análises sob prismas que privilegiam o desmascaramento da ação do capital e Estado nacional, como no estrangeiro, com autores como Théry (2002) que faz uma análise que leva em consideração o processo de integração da Pan-Amazônia, baseado no planejamento e execução de grandes obras infraestruturais. Para este autor o projeto geoestratégico brasileiro para a Amazónia ganhou força com os governos militares que, visando "integrar o imenso vazio", projetou a abertura de grandes eixos viários para a região que desempenhariam um 
papel semelhante àquele das rodovias do centro sul do país.

A tentativa de ocupar e ordenar os espaços com base no ordenamento do sistema rodoviário, apesar de ter resultado numa estratégia de sucesso relativo no sul e sudeste do país, foi de certa maneira precipitada, quando aplicada às regiões norte e nordeste. Esse processo foi capitaneado pelos governos militares e, posteriormente, patrocinado pelos investimentos do grande capital, em especial durante da implantação dos projetos de extracção mineira e da expansão da fronteira agrícola. A abertura das rodovias seguiu a lógica de acumulação do capital baseada no sul e sudeste, onde os grandes centros já estavam bastante integrados por via terrestre, mas a realidade Amazónica provaria que essa lógica não seria igualmente satisfatória por relação ao modelo de desenvolvimento regional.

O nordeste e o norte são grandes regiões administrativas que também comportam um mosaico de regiões naturais e realidades sociais e económicas muito diversas. 0 processo de ordenamento do território ganha nesses dois conjuntos regionais, vieses de relativa complexidade. Na Amazónia das décadas de 60 a 80 do século $X X$, além da ausência de eixos rodoviários terrestres consolidados, a produção nascente estava voltada para o extrativismo florestal e mineral, em que as grandes distâncias entre áreas de produção e os centros receptores e distribuidores e a vocação natural para a utilização dos transportes aquaviários impunha um planejamento que pudesse evocar estratégias de integração regional com base no aproveitamento das possibilidades dos modais rodoviário e ferroviário, mas sem esquecer o potencial e a vocação natural para o modal aquaviário.

De outra forma, os estudiosos da Amazónia que a vivem no cotidiano, como Aragón (2007) tentam entendê-la e explicá-la numa perspectiva que seja ao mesmo tempo inclusiva e sóbria para as populações locais. Para o Autor, faz-se necessário privilegiar as multirrealidades e as multifaces que compõem a imensidão desse complexo regional. Nesse sentido a compreensão visando o desenvolvimento regional passa necessariamente pela completa reformulação das velhas políticas, visando uma maior cooperação transfronteiriça nessa região. Além disso, a formação espacial em áreas de fronteira apresenta singularidades resultantes das trocas culturais e das medidas de ordenamento do território que cada Estado nacional adota.

No que tange à construção de uma rede rodoviária que atendesse aos interesses nacionais na porção leste da calha norte, pode-se dizer que a tentativa de ordenamento do território brasileiro foi feita com base na projeção de dois grandes eixos rodoviários terrestres, um no sentido sul-norte e outro no sentido leste-oeste. A estrada que configura o eixo sul-norte, corta o estado do Pará desde a cidade de Almeirim, mas só na cidade de Laranjal do Jari no extremo sul do Amapá, passa a ser denominado de BR 156, indo até a cidade de Oiapoque, sede do município homónimo no extremo norte amapaen- se, último rincão do território brasileiro em sua costa Atlántica.

Conforme atesta Théry (2002) nos planos do General Meira Mattos, geopolítico dos governos militares brasileiros, além da BR 230, que ficou mais conhecida como Rodovia Transamazónica, o outro grande eixo rodoviário terrestre, vital para a Amazónia brasileira, deveria ser a BR 210 (Figura 1, linha tracejada). A BR 210 ficaria conhecida popularmente como Rodovia perimetral norte, numa alusão à sua posição relativa de linha estratégica do perímetro norte do país. Essa rodovia partiria da cidade de Macapá no sentido este-oeste e deveria ligar todas as localidades importantes da fronteira norte brasileira. Os planeadores também imaginavam um prolongamento do eixo rodoviário em território colombiano, que permitisse a conexão com a cidade de Bogotá, capital daquele país. O traçado da rodovia BR 210 foi feito de forma a permitir fluxos em sentido latitudinal a conectar os estados do Pará, Roraima e Amazonas, na fronteira setentrional da Amazónia brasileira.

Os dois grandes eixos rodoviários transversais deveriam suportar uma rede de estradas complementares que pudesse fomentar o desenvolvimento regional no contexto mais específico de cada estado ou território. Desta forma, os grandes eixos serviriam como elemento de conexão regional em macro escala enquanto as rodovias longitudinais fomentariam o desenvolvimento no interior de cada unidade da federação. Nos grandes estados como Amazonas e Pará as BR 174 e 163 (Figura 1), respectivamente, desempenhariam um papel fundamental, complementadas por rodovias de menor tamanho nos estados do Acre, Rondónia, Roraima e Amapá.

Duas grandes rodovias longitudinais, a BR 174, em Roraima, e a BR 156, no Amapá, compõem os principais eixos na porção mais setentrional do Brasil conectando esses estados com os países do escudo Guianês. Na faixa nordeste da fronteira Amazónica, onde está situado o Amapá, a reformulação das políticas de integração do Estado nacional brasileiro continua fortemente atrelada aos velhos modelos de construção de grandes eixos viários.

Considerando a calha formada pelas altitudes do escudo Guianês no extremo norte da América do Sul e pelos baixos planaltos norte amazónicos que limitam a bacia do Amazonas em sua margem esquerda, o planejamento estratégico nacional criou e implantou na segunda metade do século XX o Projeto "Calha Norte", como referência à grande calha formada pela região situada entre esses dois grandes divisores de água. Precisamente na porção leste da chamada calha norte brasileira, onde se encontra a faixa de fronteira com a Guiana Francesa e Suriname, o Projeto Calha Norte, através de inúmeras iniciativas, com destaque para intervenções em infraestruturas, foi uma das estratégias de consolidação da soberania brasileira na região fronteiriça do norte do país. A atuação direta do Estado Nacional Brasileiro, através do Calha Norte e outros projetos, imprimiu características de apropriação social que 


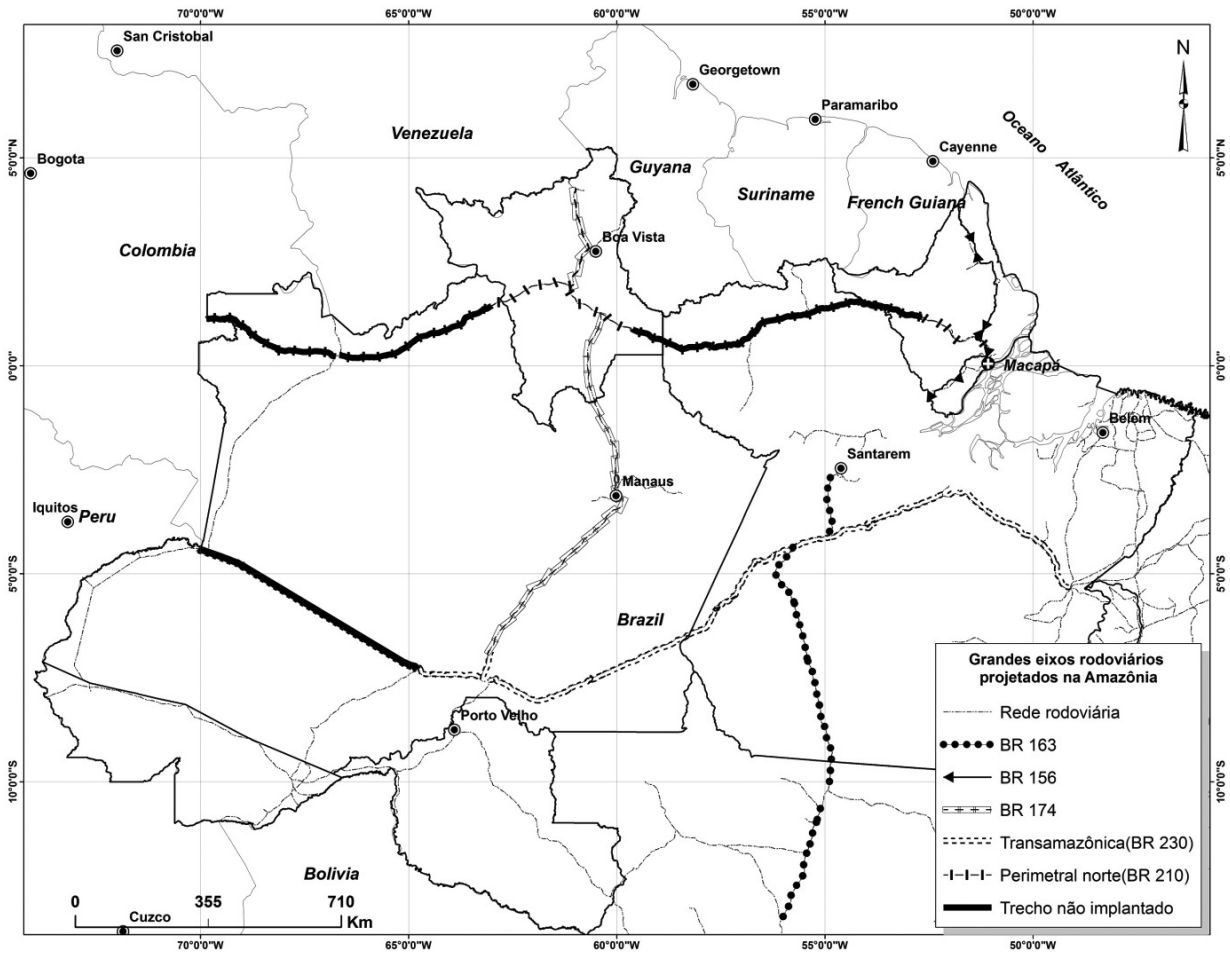

Figura 1

Grandes eixos rodoviários projetados na Amazónia brasileira.

levaram a sucessivas mudanças no ordenamento territorial do espaço amapaense.

Em solo amapaense, os aproximadamente 200 $\mathrm{km}$ implantados da BR 210, dos quais $100 \mathrm{~km}$ não pavimentados, tornaram-se também fundamentais para o desenvolvimento regional. Não obstante, esse trecho da rodovia aparece no contexto nacional como um símbolo da derrocada da empreitada integracionista e do "Brasil Grande" dos governos militares. A estrada termina abruptamente no meio da floresta, na terra indígena Wajãpi, centro-oeste do estado. A execução desse trecho da BR 210, a rodovia federal que deveria ser o eixo de sustentação Leste-Oeste do projeto geopolítico na calha norte brasileira, foi a única realizada em sua porção leste.

Gonçalves (2005) afirma que a empreitada dos macros eixos rodoviários amazónicos foi, em grande parte, frustrada pela sua inviabilidade económica. A Amazónia representava uma fronteira com novas perspectivas para o grande capital, mas que ainda se mostrava pouco significativa em função da parcas infraestruturas existentes. Esse fato refletiria as quimeras geopolíticas dos governos militares de apropriação a qualquer custo, fundamentada na máxima de “inundar de civilização" a Amazónia brasileira.

Esquecida no meio da Serra do Tumucumaque no escudo Guianês, a BR 210 apesar da malfadada ação integracionista, conseguiu consolidar localmente uma apropriação baseada na lógica dos projetos de extracção mineira de médio porte e na política da boa vizinhança, feita tanto pelas empresas mineradoras, quanto pelo governo federal e do estado. Essa política baseia-se no suporte logístico precário para plantio e transporte dos produtos rurais e na assistência social, também precária, para os pequenos produtores agrícolas e para as populações tradicionais incluídos os extrativistas da castanha da Amazónia e a própria etnia Wajãpi.

Por um caminho metodológico na análise das estruturas espaciais no Amapá pretérito.

A obtenção e tratamento de dados e informações históricas sobre o Amapá é tarefa que quase sempre remete à pesquisa documental em fontes muito incipientes. Grande parte da documentação oficial dos arquivos originais tem-se perdido no meio das inúmeras mudanças de governos instalados sem órgão que preservasse a memória documental ou ainda pela inexistência de um arquivo público. Em geral, os dados e informações estão disponíveis em documentos de fontes variadas, muitas vezes tangenciais à administração pública local ou mesmo nacional. Por isso, o acesso a dados e informações por vezes é mais frutífero nessas fontes tangenciais como é o caso dos arquivos disponibilizados pelo Governo dos Estados Unidos sobre a implantação da base aérea de Amapá. Por isso a pesquisa documental envolveu inúmeras horas dedicadas a vasculhar documentos em fontes 
alternativas aos registros públicos, inclusive um registo em vídeo documentário como foi o caso daquele dedicado ao Dr. Antunes, que retrata em boa medida a empreitada do empresário Augusto Trajano de Azevedo Antunes em terras amapaenses.

Os dados obtidos nos Anuários Estatísticos Brasileiros (AEB) disponibilizados pelo Instituto Brasileiro de Geografia e Estatística foram fundamentais para, concomitantemente às informações obtidas de outras fontes como o vídeo documentário já citado e visitas a campo, se traçar um quadro da evolução do sistema viário na relação com as atividades extrativistas, florestal e mineral, que capitanearam as dinâmicas produtivas no período de abordagem histórica que vai desde a criação do Território Federal do Amapá em 1943, até à instalação dos Governos Militares com o golpe de 1964. A estipulação desse período foi feita com base na necessidade de se estabelecer uma avaliação segura das estruturas, considerando não a sua ruptura, mas a sua manutenção dentro de um período histórico do Brasil e do Amapá, uma vez que a partir de 1964, instalam-se os governos ditatoriais, quebrando o modelo democrático de governo até então vigente no país.

A partir da pesquisa documental e bibliográfica foi possível inserir algumas informações em SIG e construir um conjunto de mapas que pudessem ilustrar para o período estudado, modelos de fixos e fluxos na perspectiva de Milton Santos. Para Santos
(1999) os sistemas de objetos são produto e processo de sistemas de ações. São os agentes sociais no território que ao imprimir suas dinâmicas o configuram dotando-o de objetos que servem aos fins determinados no processo de construção espacial. Estruturas como as rodovias, ferrovias, prédios e plantas industriais fixadas no território, por exemplo, expressam, segundo o autor, as dinâmicas que nele se processaram a revelar em boa medida o contexto histórico, económico e social que nele resultam.

Amapá, sentinela do norte: caracterização políticofísica e dinâmicas pioneiras de desenvolvimento regional.

O Amapá é atualmente um dos 26 estados da federação brasileira, constituindo um polígono relativamente isolado do território nacional. Situado no nordeste da Amazônia brasileira, o Amapá é limitado ao sul-sudeste pela foz do Amazonas, que o separa do estado do Pará. Os limites leste-nordeste são dados pelo oceano Atlântico que também o limita ao norte. A noroeste o rio Oiapoque separa o estado da Guiana Francesa e do Suriname e a oeste-sudoeste o estado é limitado pelo rio Jari que o separa do município de Almeirim, também no estado do Pará (Figura 2).

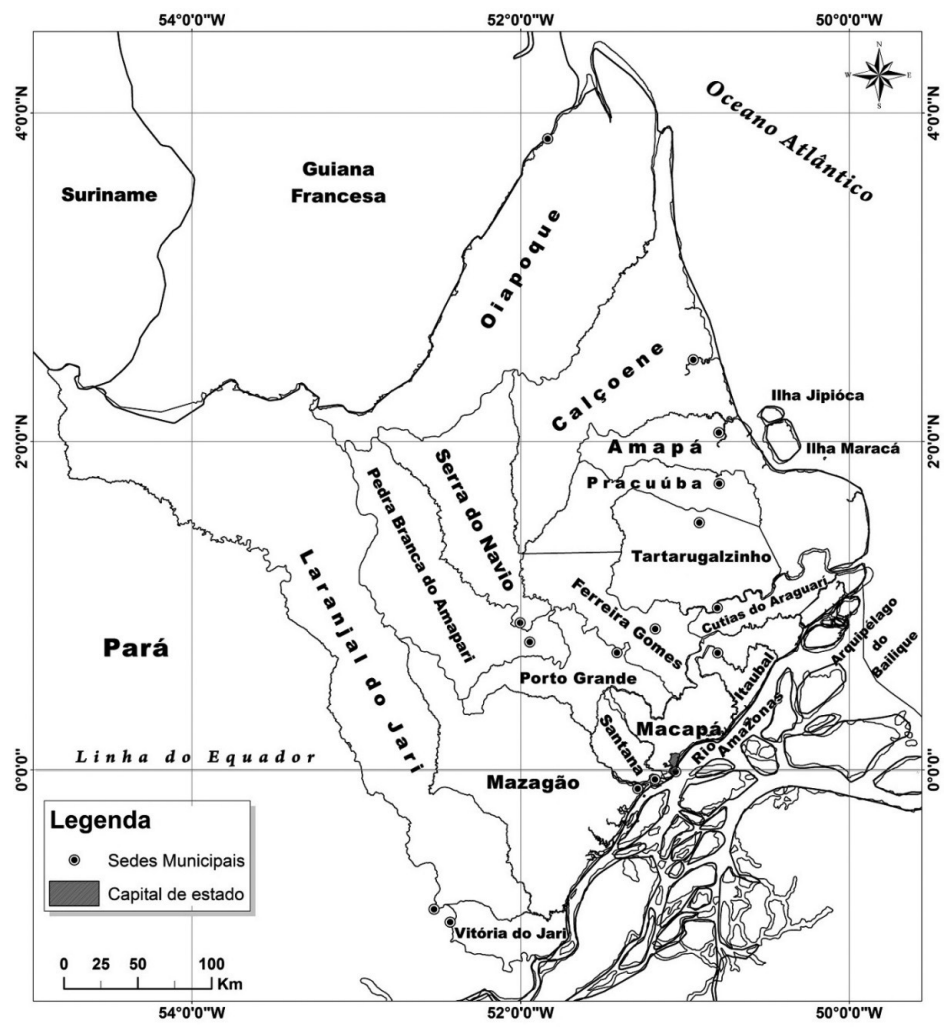

Figura 2

Divisão Político Administrativa do Estado do Amapá. 
A área total do estado do Amapá de acordo com o Macrozoneamento Económico e Ecológico - ZEE, elaborado pelo Instituto de Pesquisas Científicas e Tecnológicas do Amapá-IEPA, é de 143.453,7 km² (Amapá, 2008). As estimativas de população feitas pelo Instituto Brasileiro de Geografia e Estatística indicam uma população total de aproximadamente 766.679 habitantes (Quadro I). A maior concentração populacional está na região sudeste do estado onde está situada a área metropolitana da capital que reúne as cidades de Macapá, Santana e Mazagão, com aproximadamente 587.960 habitantes a representar $76,6 \%$ da população total do estado. O Amapá apresenta uma densidade demográfica de 5,34 habitantes/ $\mathrm{km}^{2}$ enquanto a densidade da população brasileira é de 24,02 habitantes $/ \mathrm{km}^{2}$.

Quadro I

Estimativas da população no Amapá no ano de 2015

\begin{tabular}{|l|r|}
\hline \multicolumn{2}{|c|}{$\begin{array}{c}\text { Estimativas da população residente } \\
\text { nos municípios com data de referência } \\
\text { em 1 }{ }^{\circ} \text { de julho de 2015 }\end{array}$} \\
\hline \multicolumn{1}{|c|}{ Nome do município } & População estimada \\
\hline Amapá & 8.622 \\
Calçoene & 10.163 \\
Cutias & 5.407 \\
Ferreira Gomes & 6.901 \\
Itaubal & 4.949 \\
Laranjal do Jari & 45.712 \\
Macapá & 456.171 \\
Mazagão & 19.571 \\
Oiapoque & 24.263 \\
Pedra Branca do Amapari & 13.988 \\
Porto Grande & 19.669 \\
Pracuúba & 4.531 \\
Santana & 112.218 \\
Serra do Navio & 4.938 \\
Tartarugalzinho & 15.212 \\
Vitória do Jari & 14.364 \\
\hline População do Estado & 766.679 \\
\hline
\end{tabular}

Fonte: Instituto Brasileiro de Geografia e Estatística (IBGE) - Diretoria de Pesquisas - DPE - Coordenação de População e Indicadores Sociais - COPIS.

A área que hoje configura o estado do Amapá, desde o início de sua expropriação efetiva pelos europeus no século XVII, foi palco de inúmeras disputas e divisões territoriais. Desde o século VXIII, quando os franceses consolidaram o seu estabelecimento nas terras da Guiana até ao início do século $\mathrm{XX}$, praticamente metade do atual território do Amapá esteve sob um longo e complexo litígio (Gadelha,2002; Lins 1997). A questão do contestado, como ficou conhecida a disputa entre a França e Portugal e depois entre a França e Brasil, só foi finalmente resolvida em 1902, com a promulgação do Chamado Laudo Suíço, arbitrado pela corte internacional de Berna.

As terras do losango amapaense permaneceram anexadas ao estado do Pará até 1943, quando então o Governo Federal realizou o desmembramento, transformando-as em Território Federal. O Território Federal do Amapá (TFA) foi criado com o intuito de servir de área de tamponamento da fronteira norte e da costa atlântica setentrional brasileira. Ficando sob o domínio direto da união, as ações geopolíticas abriam espaço para a permanente e rápida atuação geoestratégica do Estado Nacional brasileiro.

$\mathrm{Na}$ data de sua criação o TFA foi inicialmente dividido em quatro grandes municípios e posteriormente, em 1956, foi reconfigurado politicamente em cinco grandes municípios. A sudoeste/sudeste, Macapá, que abrigava a capital de mesmo nome e Mazagão. Ao noroeste/nordeste ficavam os municípios de Amapá, que deu origem ao nome do Território, Calçoene e Oiapoque, que fazia (e ainda faz) o contato direto com a Guiana Francesa através do rio homónimo (Amapá, 2008).

Em 1988, com a promulgação da nova constituição brasileira, o Território foi finalmente elevado à categoria de Estado Federativo. Atualmente o estado do Amapá apresenta uma divisão político administrativa com 16 municípios. Essa divisão, ocorreu a partir do fracionamento dos cinco grandes municípios do antigo TFA, que apesar de cederem áreas para a criação dos novos entes políticos, permaneceram com os respectivos nomes e sedes originais.

\section{Dinâmicas produtivas pioneiras}

O processo de dinamização económica regional no Amapá teve seus primeiros impulsos nas atividades extrativistas de larga escala, realizadas no final do século XIX e início do século XX. Essas atividades estavam relacionadas principalmente às cadeias extrativistas florestal e mineral que ainda hoje são responsáveis pela quase totalidade do que é exportado pelo estado. A expansão produtiva dessas cadeias, marcada por três grandes períodos, manteve estreita relação com a expansão e readequação do sistema viário, notadamente com os subsistemas aquaviário, rodoviário e ferroviário do Amapá. Esses períodos de dinamização económica marcados por fatores determinantes nas relações com o sistema viário evidenciaram a complexidade interativa do processo evolutivo desses dois sistemas no Amapá.

A primeira atividade em larga escala comercial no estado do Amapá, foi o extrativismo florestal, baseado na extração de produtos florestais não madeireiros (PFNM) com predominância da extração do látex e da coleta da castanha da Amazónia. Mas a extração de PFNM também foi diversificada apresentando volumes relativamente significativos na extração regional do guaximã, gomas elásticas e Timbó. A importância da extração desses produtos mereceu registros nos Anuários Estatísticos Brasileiros (AEB) pela representatividade no volume total de produção para o TFA.

Pelo contexto da segunda guerra mundial, a extração do látex pode ter sido a mais importante atividade nas três primeiras décadas após a criação do Território Federal do Amapá. Entretanto, foi a 
coleta da castanha da Amazónia que teve papel de maior destaque no processo de dinamização económica da cadeia florestal. Embora praticada desde finais do século XIX em território amapaense, os registros da atividade extrativa florestal no Amapá só começaram a constar nos relatórios estatísticos a partir de 1944.

Pelo que se infere dos registros nos AEB , apesar das fazendas de onde José Júlio coletava grande parte de sua produção se localizassem em território amapaense, até 1943 o registro e a arrecadação dos impostos eram contabilizados pelo estado do Pará. Só a partir do desmembramento do estado do Pará os registros oficiais da movimentação e da quantidade do que era produzido em solo amapaense passaram a ser contabilizados como dados de produção local (Quadro II).

O primeiro período de dinamização económica e social no Amapá foi, portanto, resultado da atividade extrativa florestal no vale do Jari, no sul do estado. Esse período foi dominado pelo modal aquaviário, predominantemente fluvial e perdurou até 1956. Entre 1944 e 1956 a atividade extrativista florestal respondeu por quase $100 \%$ de tudo o que era produzido no estado.

\section{Quadro II}

Percentagem de participação e evolução das atividades extrativas florestal e mineral na produção amapaense entre 1944 e 1964.

\begin{tabular}{|c|c|c|}
\hline Ano & $\begin{array}{c}\text { Extrativismo Mineral } \\
\text { (Toneladas) }\end{array}$ & $\begin{array}{c}\text { Extrativismo Florestal } \\
\text { (Toneladas) }\end{array}$ \\
1943 & 0 & 0 \\
1944 & 0 & 606 \\
1945 & 22 & 450 \\
1946 & 126 & 184 \\
1947 & 62 & 1108 \\
1948 & 1017 & 927 \\
1949 & 26 & 1365 \\
1950 & 3 & 1328 \\
1951 & 5 & 1566 \\
1952 & 5 & 1049 \\
1953 & 3 & 1917 \\
1954 & 3 & 2575 \\
1955 & 5 & 1678 \\
1956 & 9 & 3280 \\
1957 & 678419 & 2155 \\
1958 & 600061 & 2267 \\
1959 & 753093 & 1186 \\
1960 & 760100 & 2785 \\
1961 & 775348 & 4136 \\
1962 & 951460 & 3106 \\
1963 & 1083938 & 3221 \\
1964 & 1079132 & 2577 \\
\hline Médias & $303.765,32$ & $1.793,91$ \\
\hline
\end{tabular}

Fonte: Instituto Brasileiro de Geografia e Estatística. Anuários Estatísticos de 1944 a 1965.

De acordo com Paz (2013: 181), já em 1939 o geólogo Fritz Ackermann havia feito levantamentos de amostras e constatado a existência de minério de Ferro no Amapá, entre os municípios de Macapá e Mazagão. Mas só em 1945, essa descoberta seria oficialmente anunciada pela Hanna Mining Conpanny que anunciara a existência de considerável volume de minério de ferro na Serra do rio Vila Nova. As reservas de ferro não chegaram a ser exploradas pela empresa que, em sua avaliação, as considerou inviáveis economicamente.

Ao saber do anúncio da existência de minério de ferro na região do Vila Nova, o então governador do TFA, Janary Gentil Nunes, já em 1945 teria estimulado a busca por minerais ao oferecer prêmio em dinheiro para quem conseguisse alguma evidência de minério no estado (Paz, 2013; Monteiro, 2003). Segundo Monteiro (2003) a descoberta da existência de manganês teria sido feita em função dessa estratégia de Janary ao receber do comerciante Mário Cruz, uma pedra escura que teria encontrado às margens do rio Amapari. Posteriormente essa pedra seria confirmada por Ackermann como rocha com alto teor de manganês. Após a confirmação, em visita técnica ao Amapá o geólogo Glycon de Paiva, do Departamento Nacional de Produção Mineral (DNPM) teria viajado até à região em que a rocha teria sido encontrada e confirmado a existência do jazigo de manganês. Após a confirmação, Glycon teria passado a defender que dada a grande dimensão das reservas e a considerar a conjuntura político-econômica internacional, a exploração deveria considerar a escala global.

De acordo com Paz (2013: 182) já em 1946, o então governador do TFA anunciara oficialmente a existência de grande reserva do minério de manganês em subsolo amapaense. Monteiro (2003) defende que no mesmo ano, Janary teria articulado junto ao governo do então presidente da República Eurico Gaspar Dutra, a edição de Decreto-Lei declarando as jazidas como "reserva nacional". O documento garantiria a coordenação do processo de exploração ao recém criado TFA, sob a supervisão do Conselho Nacional de Minas e Metalurgia (CNMM), que estipulou ainda que poderiam ser contratadas empresas particulares ou de economia mista.

O processo concorrencial coordenado pelo Governo do TFA envolveu as empresas Hanna Coal \& Ore Corporation, a Companhia Meridional de Mineração e a Sociedade Brasileira de Indústria e Comércio de Minérios de Ferro e Manganês (ICOMI), empresa de Minas Gerais, criada em 1942 por Augusto Antunes de Azevedo, que após duas etapas de votação acabou por vencer (Monteiro, 2003). De acordo com narrativas de administradores ligados à Holding CAEMI, que seria posteriormente criada por Antunes, antes da concorrência o empresário teria feito inúmeras viagens à capital federal para defender que o empreendimento teria que ficar com uma empresa de capital nacional (Dr. Antunes 2013). Esse acontecimento, embora não confirmado oficialmente, pode eventualmente ter alguma relação com o fato da escolha, ter recaído para a ICOMI. Monteiro (2003) afirma que inicialmente numa primeira votação a empresa 
Hanna Coal \& Ore Corporation teria sido a vencedora, mas após a revisão do processo, por força da legislação, numa segunda votação a ICOMI teria saído vencedora.

Ao que tudo indica, Antunes pode ter-se valido nos seus argumentos de que a legislação brasileira previa a participação de empresas com pelo menos $51 \%$ de capital pertencente a brasileiros natos em empreendimentos como o que seria feito no Amapá. Esse argumento, naquela altura em que havia grande defesa do nacionalismo no país, foi, ao que tudo indica, suficiente para convencer as lideranças do estado nacional a conceder o direito de exploração a uma empresa de porte pequeno, quando comparada às duas outras de grande porte com que concorreu. Em dezembro de 1947 foi expedido o decreto presidencial que autorizava o Governo do TFA a firmar o contrato que dava à ICOMI o direito de lavra. Esse contrato, registrado em cartório da capital federal, foi firmado também no mês de dezembro de 1947.

Pelas narrativas a existência do grande potencial mineralógico já havia sido também confirmada pelo empresário Augusto de Azevedo Antunes, que teria inclusive visitado a região do Amapari. Após essa visita, ao que tudo indica ainda em 1946, o empresário parece ter imediatamente, mobilizado parte do maquinário de sua empresa em Minas Gerais para realizar as primeiras tentativas de lavra experimental do minério de manganês no Amapá.

Entre os anos de 1946 e 1948, a extração mineral teve participação significativa no volume total de produção, sendo que em 1948, com produção e exportação de mais de mil toneladas do minério de manganês, chegou a representar mais de $50 \%$ de tudo o que foi produzido na atividade extrativista. Esse volume registrado no AEB de 1950, pode ser considerado uma anomalia pelo fato de não haver ainda a capacidade industrial que seria mais tarde instalada pela ICOMI em território amapaense. Ao que tudo indica esse volume foi resultado do processo de pesquisa e confirmação das potencialidades da exploração das jazidas de manganês da Serra do Navio por Antunes (Figura 3).

O segundo período de dinamização económica tem seu início marcado pela implantação da atividade extrativa mineral em escala industrial. Esse período começa efetivamente em 1957 com a entrada em operação da Estrada de Ferro do Amapá e do Terminal de Uso Privativo (TUP) de cais flutuante construído para a exportação do minério do manganês extraído nas minas de Serra do Navio no centro-oeste do estado. No primeiro ano de exploração do manganês foram exportadas 678.419 toneladas de minério fazendo com que a atividade extrativa mineral ascendesse a quase $100 \%$ de tudo o que era produzido no estado do Amapá. A produção média anual de minério entre 1957 e 1962 foi de 753.080 toneladas de minério enquanto a média da extração florestal nesse mesmo período foi de apenas 2233,33 toneladas.

Neste segundo período, o modal aquaviário passou a dividir com a Estrada de Ferro do Amapá
(EFA) a responsabilidade pelo transporte de cargas no estado. A EFA internamente tornou-se o principal meio de transporte de cargas e o porto fluvio-oceânico instalado na vila de Santana passaria a ser o principal terminal para embarque e desembarque de cargas.

\section{Extrativismo florestal e sistema viário baseado no modal aquaviário predominantemente fluvial.}

A atividade extrativa florestal em larga escala no Amapá foi pioneiramente desenvolvida pelo cearense José Júlio de Andrade, que criou nas margens do rio Jari um grande complexo para aviamento e controle da mão de obra e dos produtos que eram extraídos da florestas. A vila de Arumanduba possuía um porto fluvial com capacidade para atracação de até 7 embarcações simultaneamente. De acordo com Lins (1997), a vila possuía ainda estação de radiofonia, armazéns, posto de correios, escolas e outros equipamentos públicos ainda pou co comuns na grande maioria das vilas e até mesmo cidades da região Amazónica na primeira metade do século $X X$

Foi o empreendimento de José Júlio que desencadeou aquela que pode ser considerada a primeira dinâmica de desenvolvimento regional no Amapá, pois explorou e movimentou grandes quantidades de mão de obra e organizou a extração de produtos florestais no sul do então TFA de maneira a configurar uma cadeia produtiva de extrativismo florestal. Mas apesar de as suas "colocações" estarem quase todas em território amapaense, a atividade comercial de José Júlio foi toda reportada ao estado do Pará até 1943.

Durante o período em que a atividade extrativa florestal foi predominante, de 1944 a 1956, a produção média anual foi de 1387,15 toneladas. Entre os anos de 1944 e 1946, portanto ainda no auge do fornecimento da borracha como matéria prima na indústria de pneumáticos durante a segunda grande guerra, a extração da borracha apresentou os maiores valores de produção correspondendo a mais de $80 \%$ do que era extraído nas florestas no Amapá. Nesse período o TFA apresentou uma produção anual média de 367 toneladas de borracha.

A partir de 1947 mesmo com o arrefecimento da produção no mercado de pneumáticos a produção da borracha continuou em patamares elevados. A produção anual média entre 1944 e 1964 foi de 483,09 toneladas, o que representou $23 \%$ do total da produção na atividade extrativista florestal no Amapá entre 1944 e 1964. A extração da borracha foi cedendo gradualmente espaço para a de outros produtos florestais não madeireiros (PFNM). A partir 1947 a coleta da castanha passou a representar o maior volume de produção com uma média anual de 1200,8 toneladas, entre 1944 e 1964 , a representar $58 \%$ do total produzido no período (Quadro III). 
Quadro III

Percentagem de participação e evolução da extração (t) dos produtos florestais não madeireiros (PFNM) na atividade extrativa florestal no Amapá de 1944 e 1964.

\begin{tabular}{|c|c|c|c|c|c|c|c|}
\hline \multirow{2}{*}{ Ano } & \multicolumn{7}{|c|}{ Produção da cadeia extrativista florestal (Toneladas) } \\
\hline & Borracha & Castanha & Timbó & Guaximã & Gomas não elásticas & Murumuru & Total anual \\
\hline 1944 & 546 & 48 & 12 & & & & 606 \\
\hline 1945 & 374 & 66 & 10 & & & & 450 \\
\hline 1946 & 181 & 3 & 0 & & & & 184 \\
\hline 1947 & 450 & 656 & 2 & & & & 1108 \\
\hline 1948 & 401 & 524 & 1 & 1 & & & 927 \\
\hline 1949 & 453 & 911 & & 1 & & & 1365 \\
\hline 1950 & 574 & 754 & & & & & 1328 \\
\hline 1951 & 576 & 990 & & & & & 1566 \\
\hline 1952 & 525 & 523 & & 1 & & & 1049 \\
\hline 1953 & 575 & 1341 & 1 & & & & 1917 \\
\hline 1954 & 1042 & 1523 & & 10 & & & 2575 \\
\hline 1955 & 720 & 819 & & 10 & 43 & 86 & 1678 \\
\hline 1956 & 676 & 2541 & & & 8 & 55 & 3280 \\
\hline 1957 & 803 & 1268 & & & 12 & 72 & 2155 \\
\hline 1958 & 414 & 1732 & & & 13 & 108 & 2267 \\
\hline 1959 & 290 & 723 & 6 & & 57 & 110 & 1186 \\
\hline 1960 & 218 & 2416 & 7 & & 16 & 128 & 2785 \\
\hline 1961 & 297 & 2916 & 8 & & 22 & 893 & 4136 \\
\hline 1962 & 165 & 2130 & 10 & & 17 & 784 & 3106 \\
\hline 1963 & 243 & 2247 & & & 8 & 723 & 3221 \\
\hline 1964 & 622 & 1086 & & & 17 & 852 & 2577 \\
\hline Médias & 483,0952 & 1200,8 & 5,7 & 4,6 & 21,3 & 381,1 & 1879,3 \\
\hline
\end{tabular}

Fonte: Instituto Brasileiro de Geografia e Estatística. Anuários Estatísticos de 1945 a 1965.

Durante toda a primeira metade do século XX, a navegação fluvial e de cabotagem era o único meio de transporte que possibilitava a ligação entre as poucas localidades existentes no território Amapaense. As rotas operadas tinham como nó principal a cidade de Belém, que se destacava na Amazónia como centro urbano polarizador. Mesmo após a criação do Território Federal do Amapá em 1957, Belém era o único centro urbano do país que mantinha permanente ligação com Macapá, a capital do recém criado território Federal do Amapá.

Embora os registros da atividade produtiva no Amapá só tenham sido contabilizados nos anuários estatísticos brasileiros a partir de 1946, os fluxos aquaviários começam a constar nos registros oficiais em 1933, mas ainda de forma genérica para todo o Amapá e como parte dos fluxos totais do Pará. Somente três anos após a separação do Amapá daquele estado esses fluxos passaram a ser contabilizados de maneira específica e considerando a movimentação nos dois portos até então existentes no território: Macapá e Oiapoque.

\section{O manganês e a implantação do extrativismo mineral em escala industrial: por um sistema viário baseado nos modais rodoviário e ferroviário}

Na constatação de Porto (2007), a estratégia de consolidação do Estado nacional brasileiro nas terras amapaenses só aconteceu após a criação do Território
Federal em 1943. Essa estratégia resultou da descoberta das reservas de manganês da Serra do Navio. Para fomentar os investimentos da Indústria e Comércio de Minérios S/A (ICOMI), consorciada com a americana Bethlehem Steel Corporation, o Estado brasileiro se comprometeu a incluir no planejamento estratégico para o TFA a construção de infraestruturas espaciais de suporte ao empreendimento mineiro. Desse compromisso resultou a construção da Usina Hidroelétrica Coaracy Nunes, situada no rio Araguari, próxima da cidade de Ferreira Gomes, uma linha de transmissão da usina até Serra do Navio e uma rede rodoviária e ferroviária que pudesse conectar esses e outros objetos espaciais importantes à instalação e funcionamento do empreendimento de exploração das jazidas de manganês de Serra do Navio.

Mas a exploração do manganês na Serra do Navio, só ficou sob o controle do capital nacional pela atuação e defesa feita por Augusto Trajano de Azevedo Antunes, empresário respeitado e com forte atuação no setor mineralógico do Brasil, que parece ter usado das prerrogativas legais e da conjuntura política nacional. Como já visto, a atuação do Governador Janary Gentil Nunes também foi fundamental para dar ao capital nacional o direito a lavra ao declarar as jazidas como reserva mineral nacional através da articulação do Decreto-Lei que a instituiu. Embora não tivesse capital para desenvolver o projeto, o empresário convenceu o Governo Federal que sua exploração por um grupo nacional tinha impor- 
tância vital para o país, dada a dimensão das reservas e o valor estratégico do minério de manganês. Conforme Monteiro (2003), a empresa de Augusto Antunes era pequena e fora obrigada a buscar parcerias para dar conta e tocar o projeto para a frente. Ao que tudo indica, mais do que o Governo Brasileiro, Antunes parece ter sido mais atento às colocações feitas pelo geólogo Glycon de Paiva do DNPM, que considerava importante levar em conta a conjuntura global para a exploração do minério. Antunes percebeu que naquela altura, os EUA, único país altamente industrializado com empresas em condições de bancar o empreendimento, carecia das reservas do manganês amapaense (Dr. Antunes, 2012).

Entre 1953 e 1954, inúmeras tentativas de firmar parcerias junto às empresas americanas do setor mineral foram feitas sem êxito, pois a condição de Antunes era de que a ICOMI detivesse o controle acionário sobre as reservas a serem exploradas. Diante do impasse e percebendo a importância estratégica da parceria com empresas de uma nação aliada, o Governo Americano mediou as negociações para que uma empresa americana pudesse financiar o empreendimento. A parceria entre a ICOMI e a Bethlehem Steel Corporation, garantiu aos EUA o acesso ao minério, cuja importação havia sido comprometida pelos estremecimentos das relações com a União das Repú- blicas Socialistas Soviéticas (URSS), seu maior fornecedor. De igual forma, o manganês extraído na Índia era de difícil acesso, uma vez que o Egito havia interrompido os fluxos pelo canal de Suez. Esses dois fatos foram cruciais na decisão do governo americano de mediar o consórcio para exploração das jazidas de Serra do Navio, aceitando o controle accionista pelo capital nacional sob a liderança de Antunes.

A logística de transportes para a exploração do manganês da Serra do Navio exigiu inúmeros investimentos em infraestruturas que seriam pioneiros $e$ mudariam completamente o sistema viário amapaense como um todo. Pode-se afirmar, pelas mudanças que implantou, que a exploração do manganês em serra do Navio, foi a dinâmica de desenvolvimento regional que mais impactou o sistema viário amapaense em seu contexto interno, provocando uma quebra de modelo. A partir dessa dinâmica os fluxos internos deixam de ser preponderantemente feitos pelo modal aquaviário e passam a se concentrar nos modais rodoviário e ferroviário, com a implantação da EFA, e os fluxos externos ganham novas rotas e destinos.

A rede viária a ser implantada para a exploração das minas de Manganês em Serra do Navio, teria como componente principal de escoamento da produção a Estrada de Ferro do Amapá (EFA) e seria complementada pelas BR 210 e 156. Também comporiam o com-

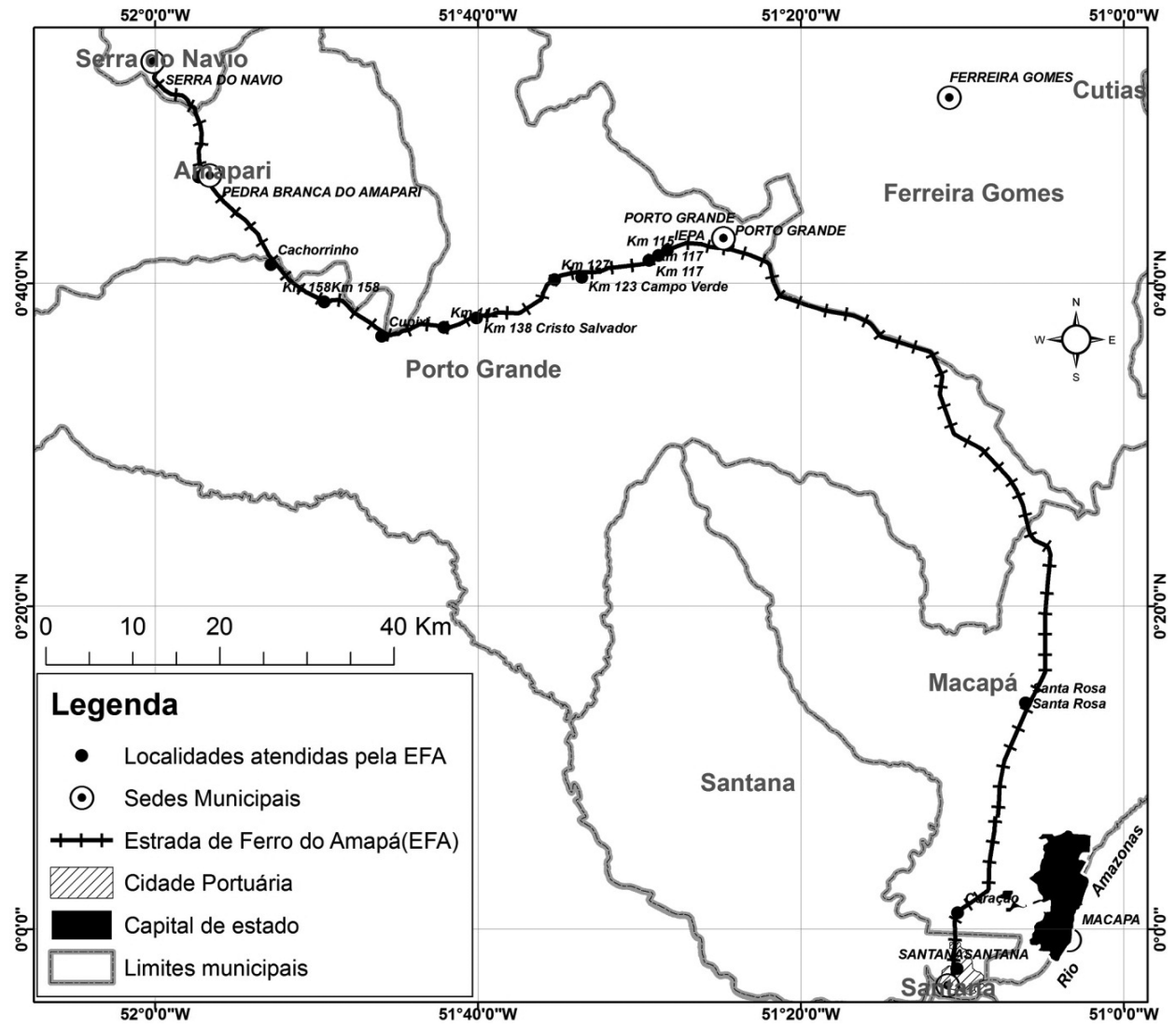

Figura 3

Traçado e municípios abrangidos pela Estrada de Ferro do Amapá. 
plexo de escoamento dois terminais de estocagem, sendo um em Serra do Navio e outro em Santana, onde também foi construído um cais flutuante para transbordo do minério estocado para os navios cargueiros. Mas a construção do cais flutuante só foi possível após o balizamento e a abertura do canal norte do rio Amazonas para a navegação de navios de grande porte, sendo essa outra importante contribuição da dinâmica da extracção do manganês na transformação do sistema viário amapaense.

Estrada de Ferro do Amapá: uma ferrovia do passado, um presente para o futuro.

A implantação da estrada de ferro do Amapá é rodeada de fatos marcantes, oriundos de uma verdadeira saga desenvolvimentista nas montanhas de Serra do Navio , no coração da selva Amazónica. A EFA, até aos dias atuais, é a única ferrovia brasileira a norte do Equador e apesar de ter apenas $193 \mathrm{~km}$ de extensão, possui um valor real, mas também simbólico importantíssimo quando consideradas as dinâmicas de desenvolvimento regional centradas no extrativismo mineral. A ferrovia que se inicia na Cidade de Serra do Navio, sede do município homónimo passa por 6 dos dezasseis municípios do Estado, serve como parte do limite para os municípios de Porto Grande e Ferreira Gomes, conecta 16 localidades, sendo quatro sedes municipais e tem seu ponto final no pátio de estocagem de minério na Cidade de Santana (Figura 3), que abriga o principal porto do estado e o cais flutuante para transbordo de minério, implantado pela ICOMI praticamente ao mesmo tempo em que a ferrovia era finalizada.

A EFA começou a ser construída em 1953 e foi concluída em 1957, um tempo recorde quando consideradas as dificuldades encontradas para a sua construção. Dentre essas dificuldades destaca-se a abertura da selva, o transporte dos dormentes a longas distâncias e a construção da ponte férrea para a transposição do rio Amapari. Mas a maior dificuldade encontrada para a construção da EFA, de acordo com depoimentos de ex-funcionários do grupo CAEMI, da qual fazia parte a ICOMI, foi a carência de mão de obra especializada, que foi superada com a vinda de técnicos e engenheiros estrangeiros.

Após finalizada, a EFA serviu basicamente para o transporte de minérios, mostrando-se importante para as dinâmicas centradas na atividade extrativista mineral. Após algum tempo, a ICOMI também implantou uma linha que denominou de "trem o colono", quando era feito o transporte de passageiros e cargas não diretamente vinculadas ao projeto de exploração do manganês.

\section{Os eixos rodoviários internos e a ampliação marginal} da rede rodoviária

O sistema rodoviário no Amapá começou a constar nos registros oficiais a partir de 1952, quando então foram contabilizados $317 \mathrm{~km}$ de rodovias federais e apenas $66 \mathrm{~km}$ de rodovias municipais não pavimentadas, totalizando $383 \mathrm{~km}$ de estradas no Amapá. Embora não se precisasse o tipo de revestimento, infere-se pelos dados do anuário estatístico brasileiro de 1956, onde começam a constar os tipos de revestimento, que boa parte das rodovias federais e municipais foram abertas sobre o leito natural do terreno e assim permaneceram por muito tempo. Entre 1956 e 1957, apenas 20 dos $447 \mathrm{~km}$ de rodovias federais existentes constavam estar sobre o leito natural. Em 1958 esses números parecem ter sido corrigidos e dos $483 \mathrm{~km}$ de rodovias federais apenas 149 apresentavam revestimento primário enquanto os restantes 283 estavam ainda sob o leito natural, situação que perdurou até 1961 (Figura 4).

Entre 1954 e 1955, portanto nos dois anos seguintes ao início da construção da EFA foram abertos $417 \mathrm{Km}$ de rodovias municipais (Figura 4). Esse salto na quantidade de quilómetros de rodovias municipais, embora não sejam especificados os meios de construção nos registros oficiais, coincidem com o período em que a ICOMI realizava as obras de construção da EFA, das vilas industriais em Serra do Navio e Santana (Vila Amazonas), além das obras do cais flutuante, também em Santana. Portanto, a primeira grande ampliação do sistema rodoviário implantado no Amapá também foi fruto da implantação da dinâmica económica engendrada pela exploração mineral a partir da década de 50 . Pode-se também dizer que houve ainda um salto qualitativo nas rodovias implantadas, pois se a ICOMI contava com uma equipa capacitada de engenheiros de estradas, é quase certo que todas as novas rodovias recebiam pelo menos revestimento primário.

No início de sua implantação o eixo rodoviário norte-sul recebeu a denominação de BR 15 e, pelo que os registros oficiais indicam, apenas essa rodovia federal havia de fato sido projetada para o território amapaense na primeira metade do século XX. Essa rodovia até 1961 possuía $432 \mathrm{~km}$ não pavimentados. Em 1962 foram construídos mais $51 \mathrm{~km}$ e iniciado o processo de pavimentação dos primeiros $116 \mathrm{~km}$, de Macapá até a entrada da cidade de Ferreira Gomes, onde se situava o entroncamento com o ramal para acesso às obras da Usina Hidrelétrica Coaracy Nunes.

Conforme se pode constatar, a rede rodoviária planejada e implantada pelo governo federal, concomitantemente à construção da EFA, fez parte de um grande projeto de integração. No caso específico do Amapá, esse projeto foi pensado de maneira a complementar a iniciativa do empresário Augusto Antunes e, por isso, foi sustentado em duas grandes rodovias federais que funcionariam como eixos rodoviários, a BR 210 e a BR 156 (Figura 5). Não por acaso, o traçado da perimetral norte ou BR 210 , passou a apenas $5 \mathrm{~km}$ das jazidas de manganês exploradas pela ICOMI e, pelo que se pode constatar dos registros oficiais, foi feito a partir da abertura da rodovia de suporte aberta pela ICOMI para implantação do projeto. Já o traçado da BR 156 foi projetado também para permitir o acesso à Usina Hidrelétrica de Coaracy Nunes 


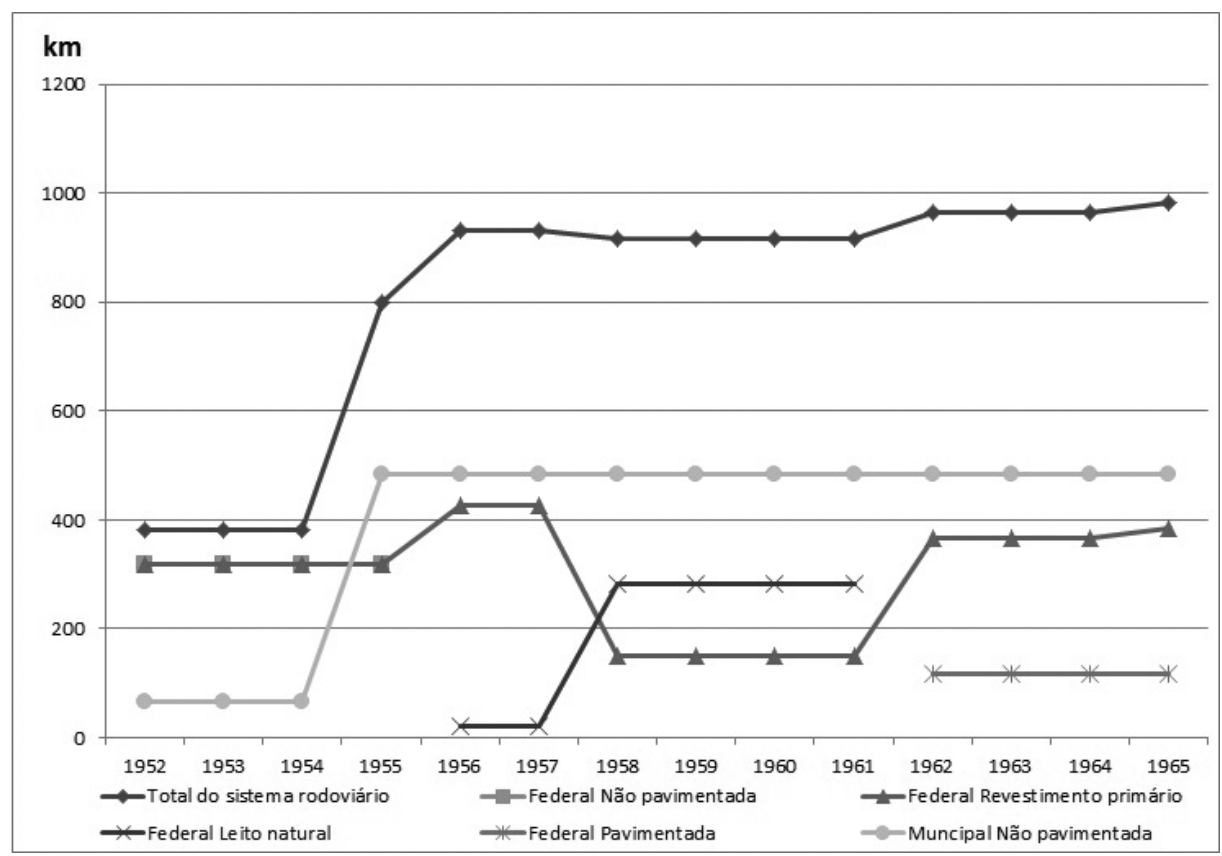

Figura 4

Evolução do Subsistema rodoviário e tipos de revestimento das rodovias existente no Amapá até 1964. Fonte: Adaptado dos dados dos AEB de 1945 a 1967 (BRASIL, 1945 a 1967).

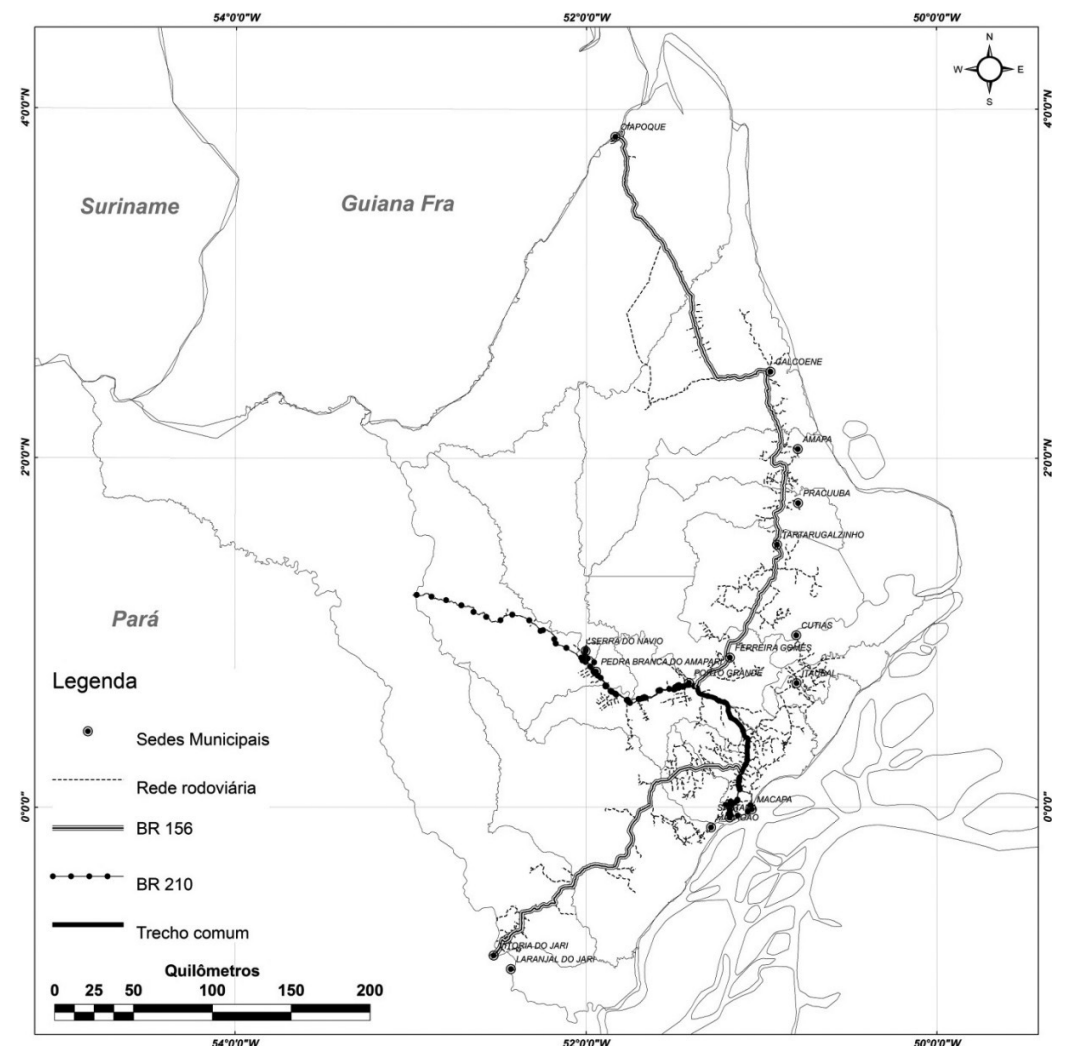

Figura 5

Atual formatação espacial das rodovias no território amapaense. 
(popularmente denominada de Paredão), construída sobre o rio Araguari no município de Ferreira Gomes, a pouco mais de $200 \mathrm{~km}$ da sede do projeto de exploração do manganês da ICOMI.

A BR 156 e a BR 210 têm um trecho comum de aproximadamente $80 \mathrm{~km}$ que se inicia no $\mathrm{km} 21 \mathrm{da}$ BR 210 e se estende até ao $\mathrm{km} \mathrm{101,} \mathrm{na} \mathrm{entrada} \mathrm{para}$ a cidade de Porto Grande (Figura 5). Compartilhando esse trecho, as BR 210 e 156 ligam a capital do estado, Macapá, a 13 das 16 sedes municipais, através de pequenas estradas locais. Em função dos riscos e da demora na travessia oceánica, após sua abertura, a BR 156 tornou-se a via preferencial de ligação entre a capital Macapá e a cidade de Oiapoque, situada nas margens do rio homónimo na fronteira norte do estado, mesmo com trechos quase intrafegáveis durante o longo período chuvoso que se estende de novembro a junho.

Outro fato que também contribuiu para a expansão da rede de estradas no interior do Amapá a partir da abertura da BR 156 foi o boom da garimpagem do ouro e da posterior mineração industrial de médio porte deste minério. Tanto a garimpagem quanto a mineração estiveram fortemente atrelados à abertura de estradas secundárias ao eixo principal formatado pelo estado nacional através da BR 156 . $O$ acesso às áreas de garimpo concentradas na região norte do estado, foi posteriormente consolidado por via terrestre com incremento do Estado. Na década de 80 do século $X X$ foi realizada a implantação de uma estrada secundária, que liga o distrito garimpeiro de Lourenço à BR 156.

\section{Considerações finais}

A evolução do sistema viário, desde a criação do Território Federal do Amapá até 1964, ou seja, nos vinte primeiros anos após o desmembramento do estado do Pará, mostra-se direta e fortemente relacionado com as dinâmicas produtivas extrativistas. No período entre 1943 e 1957, o território amapaense permaneceu relativamente isolado internamente por via terrestre, dada a precariedade das rodovias que não passavam de grandes trilhas abertas sobre o solo. Nesse período, o extrativismo de produtos florestais não madeireiros, notadamente da borracha e castanha da Amazônia, definiu o modal aquaviário como o tipo principal de transportes na recém criada unidade federativa.

A empreitada para a exploração do minério de manganês em Serra do Navio representou uma mudança no modelo viário, com a construção da Estrada de Ferro do Amapá, a abertura de novas rodovias de suporte direto ou indireto. Essa necessidade imposta pelo transporte de minérios, insumos e suprimentos à indústria mineira e às pequenas comunidades que foram surgindo, imprimiu importância fundamental aos modais terrestres para os fluxos internos a partir de então.

Fortemente dependente das dinâmicas produtivas extrativistas, o sistema viário pioneiro implantado no Amapá pode ser caracterizado, mesmo na atualidade, pela sua pouca capacidade de integração regional.
Outra ponto fraco do modelo viário é a ineficácia em fomentar o desenvolvimento regional auto-sustentado, uma vez que a relação de proporcionalidade direta a apenas duas atividades produtivas levou a infraestrutura implantada a depender da capacidade de intervenção dessas atividades, seja no lobby junto aos governos locais visando melhorias, seja através de intervenções diretas como a construção e manutenção de portos e barcos feita por José Júlio no início do século XX , ou como a implantação da EFA e de rodovias de apoio mantidas pela ICOMI até 1992.

\section{Referências Bibliográficas}

Acselrad, Henri (2001). Eixos de Articulação Territorial e Sustentabilidade do Desenvolvimento no Brasil. Rio de Janeiro, Projeto Brasil Sustentável e Democrático, Série Cadernos Temáticos, $\mathrm{n}^{\circ} 10$.

Amapá (2008). Macrodiagnóstico do Estado do Amapá: primeira aproximação do Zoneamento Ecológico Económico. Equipe Técnica do ZEE - AP, $3^{\mathrm{a}}$ ed. rev. ampl., Macapá, Instituto de Pesquisas Científicas e Tecnológicas do Amapá.

Aragón, Luiz E. (2007). Novos temas regionais para o estudo da Amazónia no atual contexto internacional. Paper 209 do Núcleo de Altos Estudos Amazónicos.

Becker, Berta K. (1998). Amazónia. São Paulo: Ática.

Brazil. Ministério da Agricultura, Industria e Commercio. Diretoria Geral de Estatística (1917). Annuário Estatístico do Brazil $1^{\circ}$. Anno (1908-1912), economia e finanças. Rio de Janeiro, Typographia da Estatística. Disponível em http://biblioteca.ibge.gov.br/bibliotecacatalogo?view=detalhes\&id=720. Acesso em 20 de março de 2015.

Brasil. Instituto Nacional de Estatística (1936). Anuário Estatístico do Brasil - Ano II (1936). Rio de Janeiro: Tipographia do Departamento de Estatística e Publicidade. Disponível em http://biblioteca.ibge. gov.br/biblioteca-catalogo?view=detalhes $\& i d=720$. Acesso em: 20 de março de 2015.

Costa, Wanderlei Messias (1997). O estado e as políticas territoriais no Brasil (6 ${ }^{\mathrm{a}}$ ed.). São Paulo: Contexto.

Cooley, Charles H. (1894). The Theory of transportation. Publications of the American Economic Association, vol. 9, issue 3 .

Dr. Antunes (2012). Direção de Sérgio Santos. Direção de produção de Luís Antonio Gerace. Minas Gerais, Agência Nacional de Cinema - ANCINE/CINEFOR Cinema e informação, Vídeo documentário em formato DVD.

Gadelha, Regina Maria A. Fonseca (2002). Conquista e ocupação da Amazónia: a fronteira Norte do Brasil. Estudos Avançados, 16(45). 
Gonçalves, Carlos Walter Porto (2005). Amazónia, Amazónias ( $2^{\mathrm{a}}$ ed.). São Paulo: Contexto.

Lins, Cristóvão (1997). A Jari e a Amazónia. Rio de Janeiro: DATAFORMA em convênio com a prefeitura Municipal de Almeirim.

Monteiro, Maurílio de Abreu (2003). A ICOMI no Amapá: meio século de exploração mineral. Novos Cadernos do NAEA, vol. 6, $n^{\circ} 2,113-168$.

Padula, Raphael (2008). Transportes - fundamentos e propostas para o Brasil. Brasília: CONFEA.

Paz, Adalberto (2013). Caboclos, extrativistas e operários: a formação da mão de obra industrial na Amazónia nos anos de 1940. Revista Mundos do Trabalho, vol. $5, \mathrm{n}^{\circ}$ 9, 171-187.

Porto, Jadson Luís Rebelo (2007). Amapá: principais transformações económicas e institucionais - 1943 2000 (2 $2^{\text {a Ed. }) . ~ M a c a p a ́, ~ E d i c ̧ a ̃ o ~ d o ~ a u t o r . ~}$

Rodrigue, J. P.; Comtois, C. \& Slack, B. (2013). The Geography of transport systems ( $3^{\mathrm{a}}$ ed.). Routledge, Nova lorque.

Santos, Milton (1999). A natureza do espaço: técnica e tempo, razão e emoção ( $3^{\mathrm{a}}$. ed.). São Paulo: Hucitec.

Théry, Hervé (2002). Novas fronteiras na Amazónia. Tercer Congreso de latinoamericanistas, Amsterdam.

Wolkowitch, Maurice (1973). Géographie des Transports. Paris: Armand Colin.

Texto recebido em/Text submitted on: 31/03/2016 Texto aprovado em/Text approved on: 09/09/2016 